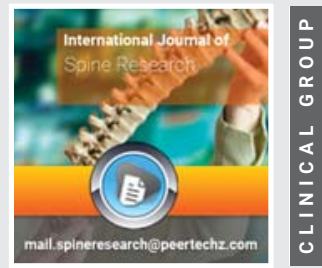

\section{Aqueous extract from Opuntia megapotamica fruit pulp promotes osteoblast activity}

\section{Valeria Gili, Juan A Laiuppa and Graciela E Santillán*}

Departamento de Biología, Bioquímica y Farmacia, Universidad Nacional del Sur, INBIOSUR-CONICET, San Juan 670, (B8000ICN) Bahía Blanca, Argentina
Received: 22 February, 2020

Accepted: 19 May, 2020

Published: 20 May, 2020

*Corresponding author: Dr. Graciela Santillán, Departamento de Biología, Bioquímica y Farmacia, Universidad Nacional del Sur, INBIOSUR-CONICET, San Juan 670, (B8000ICN) Bahía Blanca, Argentina, Tel: 54-2914595100, ext. 2442; Fax: 54-291-4595130;

E-mail: gsantill@criba.edu.ar

Keywords: Osteoblast; Opuntia; Postmenopausal osteoporosis; Osteopenia

https://www.peertechz.com

D) Check for updates

\title{
Abstract
}

Objetive: Osteoporosis and osteopenia are age-related chronic diseases with increased morbidity rates among postmenopausal women. Natural products investigation for prevention and treatment of these conditions is growing, due, in part, to the fact that they allow longer exposure times and minor secondary complications than synthetic drugs. Opuntia plants (Cactaceae) have been shown to possess a broad spectrum of medicinal properties. Opuntia megapotamica is an autochthonous species from Argentina but its action on bone metabolism has not yet been studied. The work aims is to evaluate the action of aqueous extracts of $O$. megapotamica fruits on the activity and function of osteoblasts in vitro.

Methods: Primary osteoblasts were obtained by digestion of the cranial bones of 3-5 day-old Wistar rats. Cells were treated with different dilutions of the aqueous extract (1/50-1/1000), then viability, proliferation, differentiation and mineralization were assessed at the corresponding time points.

Results: Dilution of extract $1 / 100$ induced a slight but significant increase in cell viability with respect to control ( $p<0.05)$ whereas the other conditions showed no changes. In addition, dilutions of extract $1 / 100$ and $1 / 1000$ significantly increased cell proliferation at 24 and $48 \mathrm{~h}$ with respect to the control ( $\mathrm{p}<0.05$ ). Culture mineralization, showed a rising trend with respect to the control at 15 days of treatment with 1/1000 extract dilution.

Conclusions: The results show that the aqueous extract of 0 . megapotamica fruit increases the number and improves the biological functions of osteoblasts, suggesting its potential use as an alternative treatment for postmenopausal bone deficit.

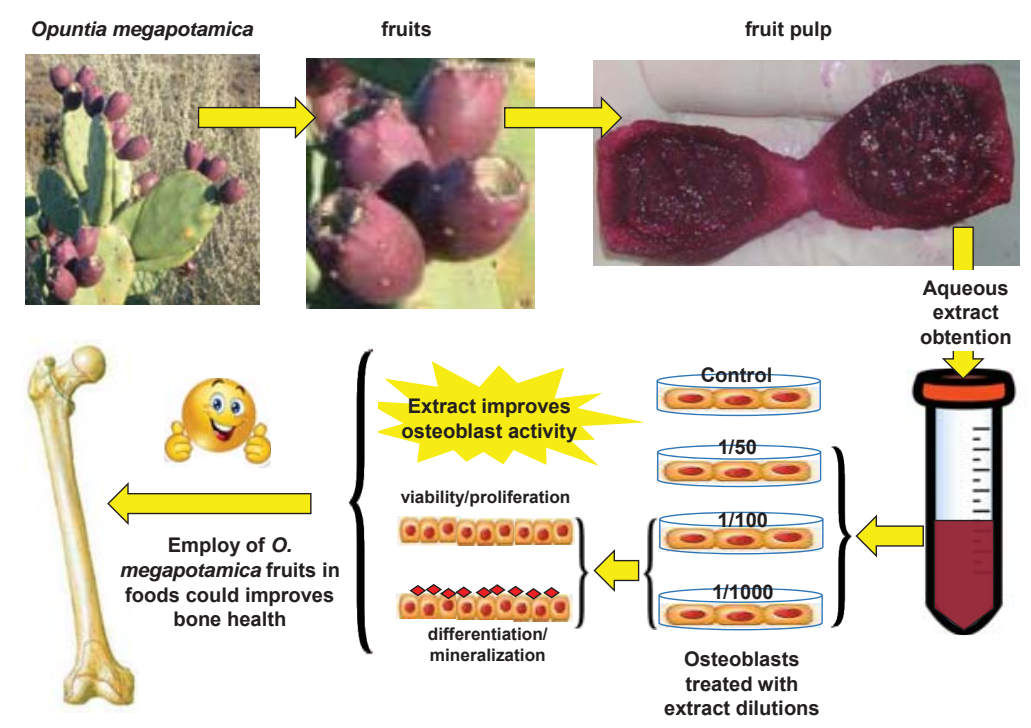




\section{Introduction}

Bone alterations and loss of bone mass have a great impact on world society, mainly in postmenopausal women. Older age, hormonal disorders, high impact diseases such as diabetes and celiac disease among other factors are frequently associated with deficits in bone formation [1-4]. Bone-forming cells, osteoblasts, originate by differentiation from mesenchymal stem cells, in response to a number of local and systemic factors [5]. The activity and function of these cells is crucial in the maintenance and regeneration of bone mass, the quality of the bone formed and the functioning of the skeletal system [6]. The main function of osteoblasts is to synthesize and secrete several proteins that integrate the organic extracellular matrix (such as cytokines, collagen and growth factors, among others) and convert the extracellular matrix into bone by mineralization [5]. Although there are numerous therapeutic approaches to stimulate bone tissue repair and regeneration, these are often insufficient. Therefore, efforts to find alternative therapies to stimulate osteogenesis should be increased $[7,8]$.

The plant kingdom is a great reservoir, not fully explored, of biologically active compounds, not only as drugs but also as models from which synthetic analogs of therapeutic application can be obtained [9-11]. The World Health Organization (WHO) proposes to increase research aimed at examining the potential benefits of medicinal plants use in different pharmacological approaches for diseases treatments [12]. There is a growing interest in the study of natural products derived from plants for treatment of bone conditions [13-17]. This is, in part, because they offer the possibility of longer exposure times and fewer secondary complications compared to synthetic drugs $[18,19]$. In this sense, in vitro and in vivo studies showed that several compounds of vegetable origin such as flavonoids, steroids, anthraquinones, polyphenols, phenolic acid, terpenoids, coumarins and glycosides stimulate the proliferation and/or differentiation of osteoprogenitor cells [18,2-24].

The Opuntia (Opuntia s.s. Mill) are American continent native cacti that constitute the most numerous genus of the subfamily Opuntioideae, family Cactaceae, which is represented by around 190 species [25]. Traditionally, Latin America people have attributed to Opuntia spp. a broad spectrum of medicinal properties, among which its use for the treatment of diabetes stands out. On the other hand, its high content of polysaccharides, phenolic compounds and minerals such as calcium gives them high nutritional value [26-28]. It has been shown that numerous herbs have therapeutic actions on bone physiology [18,20,29-31]. However, the effects of Opuntia spp. on bone tissue still remain very little explored.

Various Opuntia species have shown a variety of biological effects: hypoglycemic and lipid-lowering [32-35], antioxidant [36-40], analgesic [41], anti-inflammatory [41], antiviral [42], hepatoprotective [43], antiulcerogenic [36], antiatherogenic [44] and antitumorigenic [45,46], actions, among others. The consumption of dehydrated cladodes of Opuntia ficus indica, source of bioavailable calcium, improves Bone Mineral Density (BMD) in adult women with low bone mass [47] and in weaned growing rats $[48,49]$ On the other hand, the ethanolic extract of this same species prevents the decrease of bone mineral density induced by ovariectomy in rats [50]. The oral supply of polysaccharides isolated from cladodes, seeds and fruit pulp of Opuntia humifusa produces beneficial effects on the bone trabecular mass and on the structural properties of bone in ovariectomized female mice and rats with osteoporosis $[51,52]$. In in vitro studies, it was demonstrated that aqueous and ethanolic extracts of 0 . humifusa promote differentiation of murine osteoblasts and also decrease oxidative stress, suggesting an anabolic effect in bone [53].

Opuntia megapotamica is an autochthonous species from Argentina and, so far, has been very little studied. Complete pre-clinical studies conducted in Wistar rats, showed that flours of cladodes, fruit pulp and seeds of this Opuntia species are well tolerated when administered orally. In addition, these samples have a marked anti-hyperglycemic effect in rats with transient hyperglycemia, exert an important lipid-lowering action in diabetic rats and have positive effects on the pancreas structure and on liver function [54]. While these results may serve as a basis for future application of 0 . megapotamica as a natural therapeutic resource, there is no other background on its medicinal properties in the literature to date.

In the present work, it was hypothesized that fruit pulp of 0 . megapotamica would improve osteogenesis. In order to address this, it was studied the effect of aqueous extracts from o. megapotamica fruits pulp on the activity and function of neonatal rat calvarial cells.

\section{Materials and methods}

\section{Materials}

Alizarin Red, Ascorbic Acid, $\beta$-glycerophosphate and a-MEM (1.36 mM Ca $\left.{ }^{2+} ; \mathrm{CaCl}_{2} .2 \mathrm{H}_{2} \mathrm{O} 0.2 \mathrm{~g} / \mathrm{L}\right)$ were purchased from Sigma-Aldrich (St. Louis, MO, USA). Fetal bovine serum (FBS) was from Natocor (Córdoba, Argentina). Alkaline phosphatase (ALP) activity kit was donated by Wiener Lab. Rosario, Argentina. Neutral Red dye was donated by Paula Messina, PhD (Chemistry Department of Universidad Nacional del Sur, Bahía Blanca, Argentina). All other reagents used were of analytical grade.

\section{Vegetable material collection}

A cactus population from Opuntia (Mill.) genus that grows spontaneously in Coronel Rosales party Buenos Aires province was used, an image of it is shown in Figure 1. This material has been the object of recent systematic studies and belongs from a variety not yet described of the Opuntia megapotamica complex (Villamil, com. Pers). A reference specimen (Villamil 8829) is deposited in the Herbarium of Departamento de Biología, Bioquímica y Farmacia, Universidad Nacional del Sur (BBB), Bahía Blanca, Argentina. Material collection, postharvest processing and storage were carried out taking into account the general guidelines applicable to succulent plants and vegetable raw materials in the phytotherapeutic product industry $[55,56]$. The fruits were collected from different adult

Citation: Gili V, Laiuppa JA, Santillán GE (2020) Aqueous extract from Opuntia megapotamica fruit pulp promotes osteoblast activity. A technical note and preliminary report. Int J Spine Res 2(1): 037-045. DOI: https://dx.doi.org/10.17352/ijsr.000012 


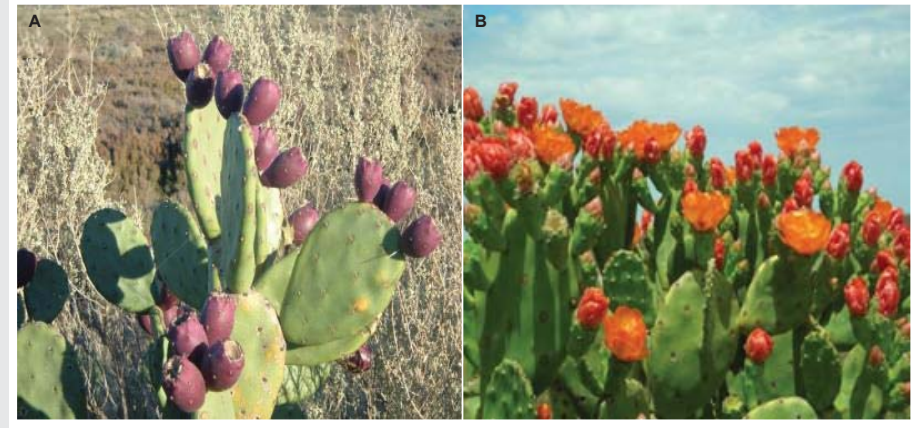

Figure 1: Opuntia megapotamica specie. Wild specimen of $O$. megapotamica growing naturally in the vicinity of the Bahía Blanca town, south of the Buenos Aires province, Argentina. A) Cladodes and ripe fruits seen in more detail. B) A plant in the state of flowering

plants chosen at random and the turgid fruits were selected based on their morphology parameters such as external color, size, surface, texture, odor, taste, and thickness (mature, about $7 \mathrm{~cm}$ long and $4 \mathrm{~cm}$ wide that were still attached to the plants). In the first stage of post-harvest processing fruit parts with deterioration, stains and/or with signs of attack by pathogens were discarded. After peeling the fruits, they were sectioned in half and the pulp was separated from the seeds. Next, fruit pulp was frozen at $-40^{\circ} \mathrm{C}$ for $12 \mathrm{~h}$ and then lyophilized. Once dry, the material was stored, under vacuum and protected from light, at $-20^{\circ} \mathrm{C}$ until the moment of its use. We worked with the dehydrated plant material because the drying process interrupts degradation caused by enzymes and prevents development of microorganisms and oxidation and hydrolysis reactions.

\section{Preparation of extracts from plant material}

Approximately $1 \mathrm{~g}$ of lyophilized material was extracted with $10 \mathrm{ml}$ of double-distilled water under stirring for $2 \mathrm{~h}$, at $25^{\circ} \mathrm{C}$. After maceration, the aqueous extract was filtered with $0.22 \mu \mathrm{m}$ pore diameter filters and frozen at $-20^{\circ} \mathrm{C}$ until further use.

\section{Cell isolation}

Calvarial cells were obtained from 3-5-day-old neonatal Wistar rats. Animals were sacrificed by fast decapitation. All procedures were carried out in conformity with the Guide for the Care and Use of Laboratory Animals published by the US National Institutes of Health (NIH Publication No. 85-23, revised 1996) under protocol $n^{0}$ 012/2014 of Institutional Animal Care and Use Committee (CICUAE) of Universidad Nacional del Sur, Argentina. The head of each animal was immersed in a series of three beakers containing $70 \%$ ethanol ( 3 times in each beaker, for 1-2 seconds) and the calvaria was extracted after removing the skin and skull tissue. After removing all soft tissue debris, the cranial bones were incubated in phosphate buffer saline (PBS) containing $4 \mathrm{mM}$ EDTA at $37^{\circ} \mathrm{C}$ for two 10 -min periods and the supernatants were discarded. Subsequently, the cranial bones were rinsed in PBS and subjected to enzymatic digestion, by incubation in PBS with collagenase (200 U / ml) for $15 \mathrm{~min}$, at $37^{\circ} \mathrm{C}$. The solution containing the cells released in this first digestion was discarded. A second enzymatic digestion was then performed, incubating the bones in PBS containing collagenase $(200 \mathrm{U} / \mathrm{ml})$ for $15 \mathrm{~min}$, at $37^{\circ} \mathrm{C}$. The solution containing the cells released in this second digestion was collected and subjected to centrifugation at $1200 \mathrm{rpm}$ for $10 \mathrm{~min}$. The supernatant was then discarded and the cell pellet was resuspended in $\alpha$-MEM supplemented with $15 \%$ FBS to stop the enzymatic action. After this, the bones underwent two other enzymatic digestions like the previous one and the collected cells were pooled with those obtained previously. Then, cells were cultured at $37^{\circ} \mathrm{C}$ in $\alpha$-MEM supplemented with $15 \% \mathrm{FBS}, 1 \%$ penicillin and streptomycin under humidified air $\left(5.5 \% \mathrm{CO}_{2}\right)$. After $24 \mathrm{~h}$, the medium was replaced by $\alpha-M E M$ supplemented with $10 \% \mathrm{FBS}, 1 \%$ penicillin and streptomycin and the cells were cultured until $\sim 80 \%$ of confluence (2-3 days). Cells were frozen in liquid nitrogen until their use.

\section{Cell culture and treatment}

Cells were thawed and seeded into $10 \mathrm{~cm}$ diameter glass Petri dishes and allowed to grow to $80 \%$ confluence. Then, cells were passed at a density of $10 \times 10^{3}$ cells $/ \mathrm{cm}^{2}$ and cultured for 3-4 days in $\alpha$-MEM supplemented with $10 \%$ FBS, in a humidified atmosphere $\left(5.5 \% \mathrm{CO}_{2}\right)$ at $37^{\circ} \mathrm{C}$. For each experiment, the cells underwent two passages, one when they were obtained before being frozen, and the other when they were counted and seeded to the various experimental conditions tested. When cells reached $80 \%$ confluence, they were starved in $1 \%$ FBS medium for 7-16 $\mathrm{h}$ before starting treatment. This procedure allows to arrest the cell cycle and thus synchronize the culture, avoiding the use of dexamethasone, which can interfere with osteogenic differentiation. Treatments were performed by replacing the medium by treatment medium ( $\alpha-M E M$ supplemented with $1 \%$ FBS, containing the indicated amounts of extract or the vehicle/water $\mathrm{pH}: 7$ used in control conditions). When experiment where performed in osteogenic conditions, $2 \mathrm{mM} \beta$-glycerophosphate and $50 \mu \mathrm{g} / \mathrm{ml}$ ascorbic acid where incorporated to treatment medium. The control or treatment medium was renewed every $2-3$ days.

\section{Cell viability assay}

Determination of cell viability was carried out using Neutral Red staining. After treatments, cells were washed with PBS $1 \mathrm{X}$ and stained with Neutral red for 2-3 h, at $37^{\circ} \mathrm{C}$. Dye excess was removed with PBS $1 \mathrm{X}$ and photograph of the cells were taken. Finally, the dye incorporated to cells was extracted with remover solution (50\% ethanol $96 \%$, $49 \%$ deionized water, $1 \%$ glacial acetic acid) and quantified, at $540 \mathrm{~nm}$, in a spectrophotometer with plate reader (Sinergy HT plate reader, BioTek).

\section{Cell proliferation assay}

Determination of cell proliferation was carried out using Crystal Violet staining. After treatments, the cells were washed with PBS $1 \mathrm{X}$, and fixed with pure methanol, for 10 minutes at $37^{\circ} \mathrm{C}$. The alcohol was then removed with distilled water and staining was started with Crystal Violet dye, which was performed for 30 minutes at room temperature. Excess dye was removed with distilled water. Finally, the dye was extracted, for 30 minutes at room temperature, with Triton $0,2 \%$. Spectrophotometric quantification of the extracts was carried out in plate reader, at a wavelength of $590 \mathrm{~nm}$. 


\section{Alkaline phosphatase (ALP) activity}

The ALP activity of cell was colorimetrically determined using a commercially available kit (Wiener Lab., Rosario, Argentina); this assay uses sodium phenylphosphate as a substrate; ALP in the presence of methyl propanol amine ( $\mathrm{pH}$ 10) releases phenol. The phenol released is combined with a color generating reagent solution of 4-amino-antipyrine and ferrocyanide and quantified at $520 \mathrm{~nm}$. The ALP activity was measured after the indicated cell treatments. Briefly, cell layers were washed with PBS and then cells were incubated with $50 \mu \mathrm{l} /$ well of PBS containing $0.2 \%$ Triton for $10 \mathrm{~min}$ at $37^{\circ} \mathrm{C}$. Follow $250 \mu \mathrm{l}$ of substrate was added to each sample and it was incubated for $10 \mathrm{~min}\left(37^{\circ} \mathrm{C}\right)$ before the addition of $1.25 \mathrm{ml}$ of color reagent and quantification as indicated above. A blank (B) and standard (S) (200 IU/L phenol) were also processed. Optical density of the samples (D) was measured and ALP activity was calculated as follows: ALP $(\mathrm{IU} / \mathrm{L})=200 \mathrm{IU} / \mathrm{Lx}(\mathrm{D}-\mathrm{B}) /(\mathrm{S}-\mathrm{B})$.

\section{Alizarin red staining}

Calvarial osteoblasts seeded in 48-well plates were cultured and treated as above for 15 days. The cells were then fixed with $2 \%$ glutaraldehyde in PBS ( $\mathrm{pH} 7.4$ ) at room temperature for 10 min, washed three times with PBS, and then incubated with $2 \%$ Alizarin Red ( $\mathrm{pH} \mathrm{4.2)}$ for $30 \mathrm{~min}$ at $37^{\circ} \mathrm{C}$. The cells were washed thoroughly with deionized water. Stained cells were observed under inverted microscope (Carl Zeiss, USA) and photomicrographs captured using image analyzer (Carl Zeiss, USA). Following staining technique, evaluation of mineral distribution and inspection of fine structures by microscopy was performed. Then for quantification of Alizarin Red staining, the samples were incubated with $0.5 \mathrm{ml}$ of $500 \mu \mathrm{M}$ $\mathrm{NaOH}$ during $5 \mathrm{~min}$ and O.D. (Absorbance) was measured in the plate reader spectrophotometer at $548 \mathrm{~nm}$.

\section{Statistical analysis}

InfoStat software was employed. Variance Analysis (ANOVA) was used to determine differences between the average values of several statistical populations. The mean values were compared by the post hoc test of multiple comparisons by Bonferroni. The letters $(a-b-c)$ indicate significant differences $(p \leq 0,05)$ between the groups. The represented values correspond to the average \pm standard deviation (SD). The total number of samples is indicated in the legend of each figure or table.

\section{Results}

\section{Effect of aqueous extract from 0 . megapotamica fruits on cell viability of rat calvarial cell cultures}

In order to study the effect of extract from 0 . megapotamica fruits pulp on cell viability of rat calvarial cultures, we used the Neutral Red staining. It is extensively employed as a convenient and rapid assay for measuring cell viability. It is a well-known quantitative colorimetric method based on the uptake of the weakly cationic dye Neutral Red which enters into the cell by diffusion through the cell membrane. Then, the dye accumulates in the lysosomes of living cells [57]. The cells were treated with different dilutions $(1 / 50,1 / 100,1 / 1000)$ of aqueous extract for a period of 7 days after which viability assay was performed as indicated in Materials and Methods. In none of the conditions treated with the different dilutions of the extract decreased cell viability was observed. In contrast, 1/100 extract dilution caused a statistically significant increase on cell viability with respect to the control (Figure 2). This data suggest that aqueous extract from 0 . megapotamica fruit pulp does not elicit negative effects on the viability of rat calvarial cells.

\section{Effect of extract from 0 . megapotamica fruits on cell proliferation of rat calvarial cell cultures}

To assess the effect of aqueous extract from 0. megapotamica fruits pulp on cell proliferation, studies were performed by staining with crystal violet. This is a fast, efficient, accurate, sensitive and reliable method to detect changes in both adhesion and in vitro cell proliferation as well as for cytotoxicity studies. The dye interacts with proteins and DNA. Thus, color intensity is directly proportional to the cell biomass and can be easily measured by spectrophotometry. Therefore, increases in the cell number of a sample, result in a quantitative increase in staining. Similarly, when cells lose their adhesion, they detach from cell population, resulting in decreased staining [58]. Cells

A
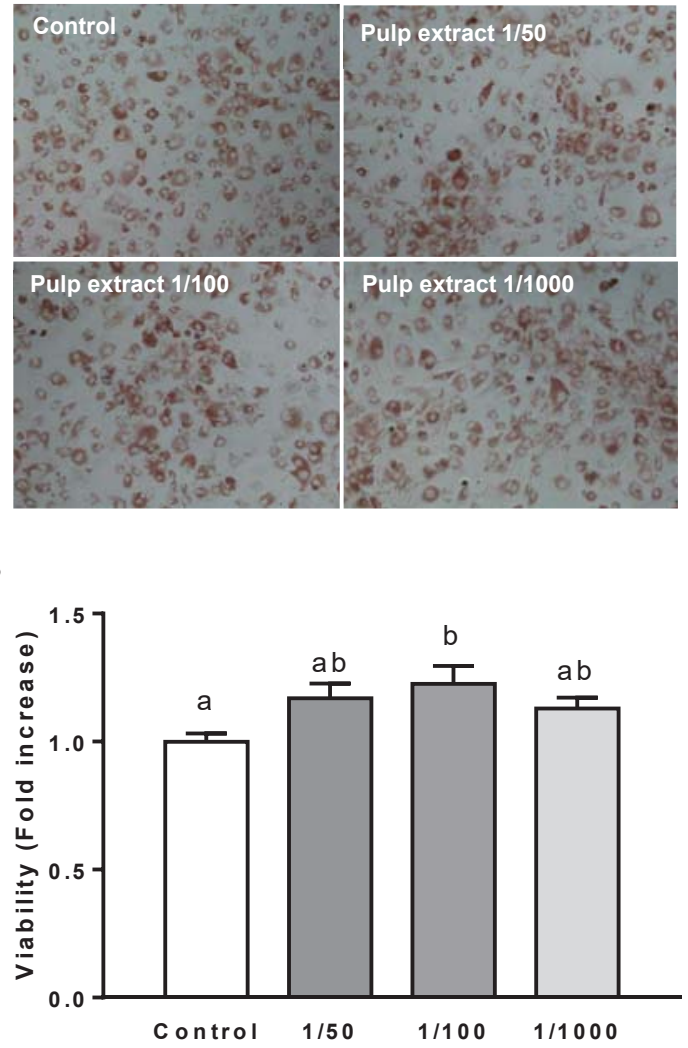

Figure 2: Effect of 0 . megapotamica aqueous pulp extract on cell viability of neonatal rat calvarial primary cultures. Cells were treated with vehicle (control) or the indicated dilutions of 0 . megapotamica fruit pulp extract for 7 days. Then, cell viability was determined by neutral red staining as indicated in Materials and Methods. A) Representative images of cells stained with neutral red are shown; B) Data represent the mean \pm SD from at least three independent experiments, each performed with 4 wells per condition. Different letters indicate statistical differences (ANOVA -Bonferroni $\mathrm{p}<0.05$ ).

Citation: Gili V, Laiuppa JA, Santillán GE (2020) Aqueous extract from Opuntia megapotamica fruit pulp promotes osteoblast activity. A technical note and preliminary report. Int J Spine Res 2(1): 037-045. DOI: https://dx.doi.org/10.17352/ijsr.000012 
were treated with different dilutions $(1 / 50,1 / 100,1 / 1000)$ of aqueous extract for 24,48 and $72 \mathrm{~h}$ and then where stained with crystal violet as indicated in Materials and Methods. It was only detected changes in those conditions treated with the $1 / 100$ and 1/1000 extract dilutions, which showed a significant increase in crystal violet staining at 24 and $48 \mathrm{~h}$ respect control. This results suggest that the extract does not exhibit cytotoxicity or affect cell adhesion. In addition, it stimulates cellular proliferation at 1/100 and 1/1000 dilutions (Figure 3 ).

\section{Effect of extract from 0. megapotamica fruits on ALP activity in rat calvarial cell cultures}

Alkaline phosphatase (ALP) activity is considered an earlystage differentiation marker of the osteoblast phenotype. In rat calvarial cell cultures, it has been shown that ALP increases in the first weeks (4-10 days) of culture in osteogenic medium [59-61]. Thus, in order to evaluate the effect of extracts from 0 . megapotamica fruits pulp on rat calvarial cell differentiation into osteoblast, ALP activity was measured in cells treated with different dilutions $(1 / 50,1 / 100,1 / 1000)$ of aqueous extract for 7 days in osteogenic medium, as indicated in Materials and Methods. At the time studied, vegetal extracts didn't stimulate enzyme activity and even a slight decrease was found in those cells exposed to dilution $1 / 50$ (Figure 4).

\section{Effect of extract from 0 . megapotamica fruits pulp on mineralization of rat calvarial cell cultures}

Mineralization is considered a functional in vitro endpoint reflecting advanced osteoblastic cell differentiation [59]. Rat calvarial cells reach a mature osteoblast stage after long incubation times ( $>15$ day) in osteogenic medium. Mineralization nodules can be visualized around day 15-20, or even later in such conditions [59-61]. In order to study if extract from 0 . megapotamica fruits pulp elicit any action in rat calvarial cell culture mineralization, the effect of cell treatment with aqueous extract on extracellular matrix mineralization after long incubation times was assessed. This was performed

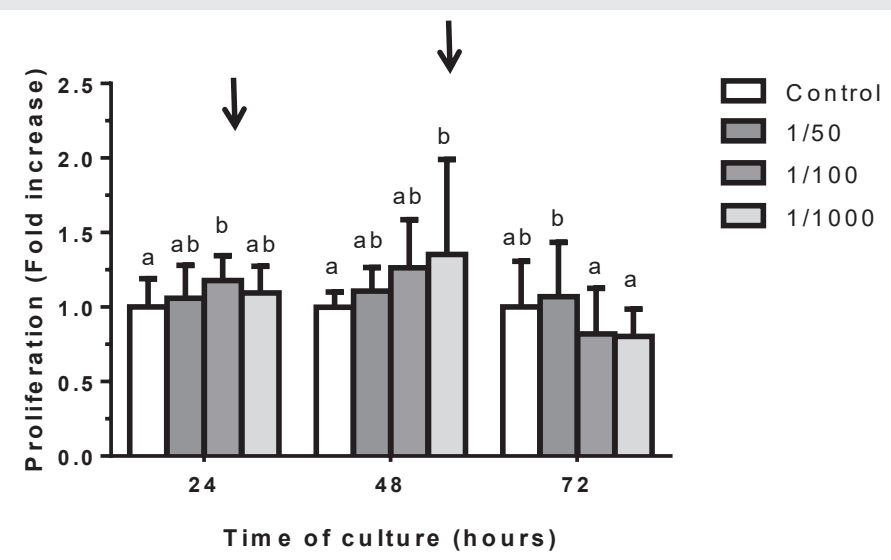

Figure 3: Effect of 0 . megapotamica aqueous pulp extract on cell proliferation of neonatal rat calvarial primary cultures. Cells were treated with vehicle (control) or the indicated dilutions of 0 . megapotamica extract for 24,48 , and $72 \mathrm{~h}$. Then cell proliferation was determined as indicated in Materials and Methods. Data represent the mean \pm SD from at least three independent experiments, each performed with 4 wells per condition. Different letters indicate statistical differences (ANOVA -Fisher $p<0.05)$

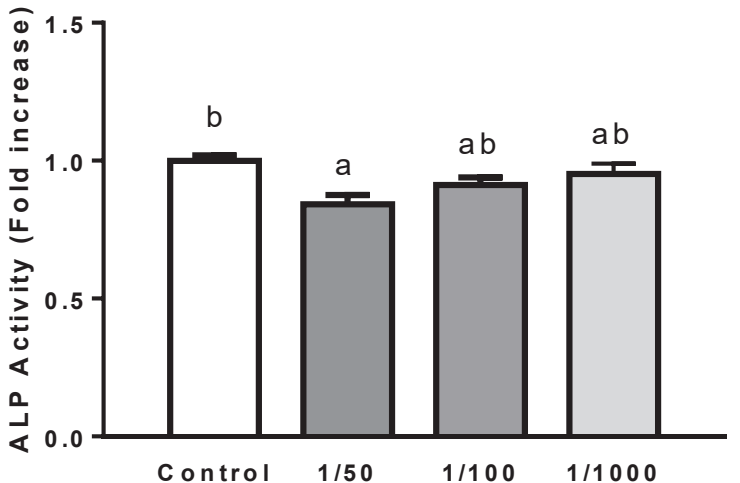

Figure 4: Effect of O. megapotamica aqueous pulp extract on Alkaline Phosphatase (ALP) Activity of neonatal rat calvarial primary cultures. Cells were treated with vehicle (control) or the indicated dilutions of 0 . megapotamica extract for 7 days in osteogenic medium. Then, quantification of ALP activity was determined as indicated in Materials and Methods. Data represent the mean \pm SD of at least three independent experiments, each performed with 4 wells per condition. Different letters indicate statistical differences (ANOVA -Bonferroni $p<0.05$ ).

by determining the calcium deposits on cell cultures using the Alizarin Red organic dye, as described in Materials and Methods. Cells were treated with different dilutions of aqueous extract $(1 / 50,1 / 100,1 / 1000)$ in osteogenic medium for 15 days. Cells grown in the presence of $1 / 100$ extract dilution showed a tendency to reduce calcium deposition, respect to control. While, cell treatment with 1/1000 extract dilution showed a tendency to increase mineralization with respect to control (Figure 5). This result suggests that long time exposition of cells to $1 / 100$ dilution does not favor osteoblasts mineralization whereas the most diluted extract does it.

\section{Discussion}

In the present study, we show for the first time an evaluation of the osteogenic potential of extracts from 0 . megapotamica fruit pulp using neonatal rat calvarial cells cultures. This cultures are a heterogeneous cell population majorly containing mesenchymal stem cells, committed osteoprogenitor cells, preosteoblasts and osteoblasts. Under appropriate conditions, these cell cultures can differentiate into osteoblasts, condrocytes or adipocytes as it has been described $[62,63]$. Under osteogenic conditions, the osteoblasts precursor cells have an osteoblast development pattern similar to in vivo bone formation. Thus, these cultures are a wellaccepted model of osteogenesis in vitro. During the culture proliferative phase, the cells undergo DNA synthesis and cell division, resulting in a rapid increase in cell number until confluence. Then, proliferation is arrested, and begin to sequentially increase the mature osteoblast characteristics, such as alkaline phosphatase (ALP) production, conversion of procollagen to collagen, and deposition of extracellular matrix on the substrate, which is subsequently mineralized [59-61]. The conducing mechanism of osteogenesis has not been fully clarified. Although various osteogenic formulations are known, as well as the importance of each one of their constituents for induction of in vitro osteogenic differentiation, this has not yet been fully optimized, generating wide interest in discoverying new osteogenic active principles [64]

Citation: Gili V, Laiuppa JA, Santillán GE (2020) Aqueous extract from Opuntia megapotamica fruit pulp promotes osteoblast activity. A technical note and preliminary report. Int J Spine Res 2(1): 037-045. DOI: https://dx.doi.org/10.17352/ijsr.000012 


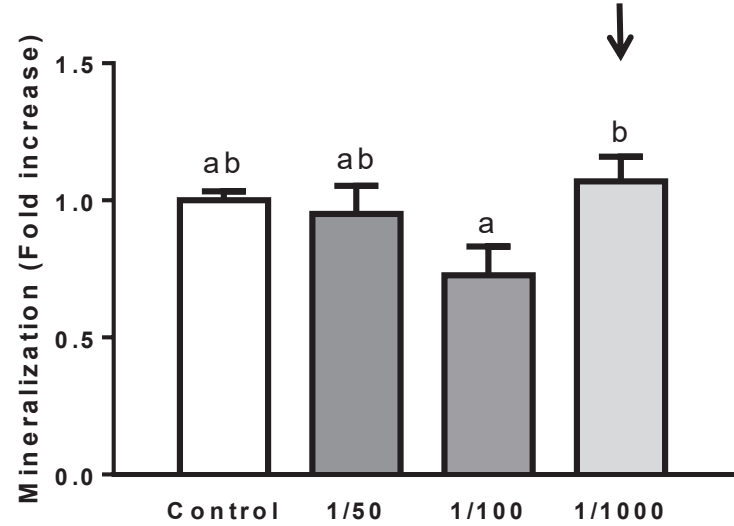

Figure 5: Effect of 0 . megapotamica aqueous pulp extract on mineralization of neonatal rat calvarial primary cultures. Cells were treated with vehicle (control) or the indicated dilutions of 0 . megapotamica extract for 15 days in osteogenic medium. Then, cultures mineralization was determined by Alizarin red staining as indicated in Materials and methods. Data represent the mean \pm SD of at least three independent experiments, each performed with 4 wells per condition. Different letters indicate statistical differences (ANOVA - Bonferroni $p<0.05$ ).

One of the criteria used to identify active ingredients of compounds at the bone level comprises the lack of toxicity and the promotion of osteoblast activity. In this sense, our results show that aqueous extracts from 0 . megapotamica fruit pulp are not toxic for osteoblast, because no negative effect on cell viability or adherence were observed at any of the dilutions used here. We employed a considerably long time (7 days), during which no change in cell morphology in the different conditions were observed respect to control (not shown). Thus, suggesting that the extract do not elicit negative effects on cell physiology in the short nor in the long time. Moreover, a statistically significant augment on cell viability was observed at dilution 1/100. This could be due to an increase in cell number since the extract induced a significant stimulation of cell proliferation at dilution $1 / 100$ and $1 / 1000$. The stimulation of cell proliferation is also a beneficial feature of the extracts because of its potential application for the treatment of bone conditions such as osteoporosis or fractures, by promoting an increase in the size of the active cell population. In agreement with our results, extracts of fruits of other Opuntia species have been shown to stimulate cell proliferation, such as 0 . Humifusa on MC3T3-E1 osteoblastic cells [53], and 0. ficus indica on human fibroblasts and keratinocytes [65]. Unlike, antiproliferative effects for extracts of fruits of 0 . humifusa have been evidenced in human cervical carcinoma cells [45], and for 0. ficus indica in human colorectal carcinoma (Caco-2) cells [66]. Of relevance, we have not found studies on the effect of extracts of 0 . megapotamica on the growth of tumor cells, which we visualize interesting for future investigations.

Another desirable effect of active principles at the bone level is promoting cell differentiation, since increases in the population of mature osteoblasts would favor bone formation. ALP is a protein involved in bone metabolism and one of the marker enzymes of mature osteoblasts, which plays an important role during calcification in vitro [67]. Its level commonly increases in the early period of osteoblastic differentiation and decreases in the mineralized period [68]
Our results show that the extracts, at the dilutions used here, do not significantly affect ALP activity. In discrepancy with our results, in vitro studies demonstrated that aqueous and ethanolic extracts of Opuntia humifusa promote differentiation of murine osteoblasts, suggesting an anabolic effect in bone [53].

Bone mineralization occurs by a set of physicochemical and biochemical processes that facilitate the deposition of hydroxyapatite crystals both along the collagen fibrils in the extracellular matrix, as well as within the lumen of the matrix vesicles derived from osteoblasts $[69,70]$. In our study we did not detect significant change in culture mineralization by treatment with 0 . megapotamica fruit extract. However, the 1/1000 dilution showed a tendency to increase mineralization, suggesting that the extract can elicit a positive anabolic effect on bone. In agreement with this, studies in Mexican adult women have shown that the intake of dehydrated cactus of 0 . ficus indica improves bone mineral density and calciuria [47]. Also, studies on bone metabolism in rats suggests that supplementation with 0 . humifusa would have a positive effect on bone formation and the achievement of peak bone mass in the growth period by increasing the levels of the osteogenic marker osteocalcin [48]. The active compounds of 0 . megapotamica fruit extracts and the mechanisms of action involved on osteoblast physiology are not known and they would be an interesting goal for future research.

Opuntia megapotamica is an autochthonous species from Argentina. Complete pre-clinical studies conducted in Wistar rats, showed that flours of cladodes, fruit pulp and seeds of this cactaceae are well tolerated when administered orally [54]. These results, together with the present study, may serve as a basis for future chemical analysis of 0 . megapotamica extracts and for investigations on application of 0 . megapotamica as a natural therapeutic resource for treatment of metabolic bone diseases. It is relevant to consider the ecological, economic and social advantages that the medical and/or nutraceutical use of 0 . megapotamica could have, since it is a rustic plant, easy to spread, manipulate and process and that grows in arid and semi-arid zones where other crops don't develop naturally.

In addition, it is important to note that plant extracts as other naturally available materials such as vitamins, carbohydrates and biodegradable polymers, among others, can act as solvents, reducing agents and/or stabilizers in the synthesis of nanoparticles for development of bio-materials applicable in medicine [71-73]. In this sense, we consider that 0 . megapotamica extracts are of potential application in the biological or chemical synthesis of hydroxyapatite nanoparticles for use in certain medicine branches such as orthopedics, orthodontics and plastic surgery. Related to this, there is a great interest in replacing hazardous materials with green chemicals in order to protect human health and the environment $[74,75]$.

\section{Potential clinical value}

These findings indicate that 0 . megapotamica is a target of interest for the search for new osteogenic drugs and also

Citation: Gili V, Laiuppa JA, Santillán GE (2020) Aqueous extract from Opuntia megapotamica fruit pulp promotes osteoblast activity. A technical note and preliminary report. Int J Spine Res 2(1): 037-045. DOI: https://dx.doi.org/10.17352/ijsr.000012 
presents potential application as a complementary therapy to current treatments for postmenopausal osteoporosis.

\section{Conclusion}

In conclusion, our results suggest that extracts of 0 . megapotamica fruit pulp have a beneficial effect on the activity and function of osteoblasts. This together with the ecological, economic and social advantages of Opuntia spp. cultivation will be a starting point to promote the implementation of clinical studies with fruit extracts of 0 . megapotamica, as a potential bone anabolic agent for the treatment of bone deficiency associated diseases, including postmenopausal osteoporosis.

\section{Acknowledgments}

V.G., J. A. L. and G.S. are researchers from the Departamento de Biología, Bioquímica y Farmacia, Universidad Nacional del Sur and Instituto de Ciencias Biológicas y Biomédicas del Sur (INBIOSUR UNS-CONICET). J. A. L. is a posdoctoral fellowship from Consejo Nacional de Investigaciones Científicas y Tecnológicas (CONICET). G. S. is member of the Research Career from CONICET. This research was supported by Grants PGI 24/B274 and 24/B255, from Universidad Nacional del Sur, and PIP 11220130100307CO from CONICET to G. S.

\section{References}

1. Boonen S, Vanderschueren D, Cheng XG, Verbeke G, Dequeker J, et al. (1997) Age-related (type II) femoral neck osteoporosis in men: biochemical evidence for both hypovitaminosis D- and androgen deficiency-induced bone resorption. J Bone Miner Res 12: 2119-2126. Link: https://bit.ly/2zeAUJj

2. Kurra S, Fink DA, Siris ES (2014) Osteoporosis-associated fracture and diabetes. Endocrinol Metab Clin North Am 43: 233-243. Link: https://bit.ly/2AAxHUL

3. Gonnelli S, Caffarelli C, Giordano N, Nuti R (2015) The prevention of fragility fractures in diabetic patients. Aging Clin Exp Res 27: 115-124. Link: https://bit.ly/2ZICCTU

4. Schacter GI, Leslie WD. Diabetes and Bone Disease. Endocrinol Metab Clin North Am 46: 63-85.

5. Garg P, Mazur MM, Buck AC, Wandtke ME, Liu J, et al. (2017) Prospective Review of Mesenchymal Stem Cells Differentiation into Osteoblasts. Orthop Surg 9: 13-19. Link: https://bit.ly/2z3N4VD

6. Neve A, Corrado A, Cantatore FP (2011) Osteoblast physiology in normal and pathological conditions. Cell Tissue Res 343: 289-302. Link: https://bit.ly/3cL1j07

7. Lyritis GP, Georgoulas T, Zafeiris CP (2010) Bone anabolic versus bone anticatabolic treatment of postmenopausal osteoporosis. Ann N Y Acad Sci 1205: 277-283. Link: https://bit.ly/2ygPrnn

8. Sun S (2008) Bone disease drug discovery: examining the interactions between osteoblast and osteoclast. Expert Opin Ther Targets 12: 239-251. Link: https://bit.ly/3fXbY9M

9. Baerheim Svendsen A, Scheffer JJ (1982) Natural products in therapy Prospects, goals and means in modern research. Pharm Weekbl Sci 4: 93-103. Link: https://bit.ly/2WK6Gad

10. Garro HA, Pungitore CR (2015) Coumarins as Potential Inhibitors of DNA Polymerases and Reverse Transcriptases. Searching New Antiretroviral and Antitumoral Drugs. Curr Drug Discov Technol 12: 66-79. Link: https://bit.ly/2TB9Vin
11. Malongane F, McGaw LJ, Mudau FN (2017) The synergistic potential of various teas, herbs and therapeutic drugs in health improvement: a review. $J$ Sci Food Agric 97: 4679-4689. Link: https://bit.ly/2LGRog3

12. World Health Organization (2004) Nuevas directrices de la OMS para fomentar el uso adecuado de las medicinas tradicionales. Link: https://bit.ly/2XbhLjp

13. Abdul Jalil MA, Shuid AN, Muhammad N (2013) Osteoporotic fracture healing: potential use of medicinal plants from the tropics. Curr Drug Targets 14: 1651 1658. Link: https://bit.ly/3dZjSxB

14. Basu A, Masek E, Ebersole JL (2018) Dietary Polyphenols and Periodontitis-A Mini-Review of Literature. Molecules 23.pii: E1786. Link: https://bit.ly/3g6efjd

15. Lambert MNT, Hu LM, Jeppesen PB (2017) A systematic review and metaanalysis of the effects of isoflavone formulations against estrogen-deficient bone resorption in peri- and postmenopausal women. Am J Clin Nutr 106: 801 811. Link: https://bit.ly/2ygROqh

16. Dietz BM, Hajirahimkhan A, Dunlap TL, Bolton JL (2016) Botanicals and Thei Bioactive Phytochemicals for Women's Health. Pharmacol Rev 68: 1026-1073. Link: https://bit.ly/3bS8UJ3

17. Wu L, Ling Z, Feng X, Mao C, Xu Z (2017) Herb Medicines against Osteoporosis: Active Compounds \& Relevant Biological Mechanisms. Curr Top Med Chem 7: 1670-1691. Link: https://bit.ly/3cMJQ7o

18. An J, Yang H, Zhang Q, Liu C, Zhao J, et al. (2016) Natural products fo treatment of osteoporosis: The effects and mechanisms on promoting osteoblast-mediated bone formation. Life Sciences 147: 46-58. Link: https://bit.ly/2zQ8eGI

19. An J, Hao D, Zhang Q, Chen B, Zhang R, et al. (2016) Natural products for treatment of bone erosive diseases: The effects and mechanisms on inhibiting osteoclastogenesis and bone resorption. Int Immunopharmacol 36 118-131. Link: https://bit.ly/2yjOACw

20. Rufus P, Mohamed N, Shuid AN (2013) Beneficial effects of traditional Chinese medicine on the treatment of osteoporosis on ovariectomised rat models. Curr Drug Targets 14: 1689-1693. Link: https://bit.ly/2ToQedh

21. Srivastava S, Bankar R, Roy P (2013) Assessment of the role of flavonoids for inducing osteoblasts differentiation in isolated mouse bone marrow derived mesenchymal stem cells. Phytomedicine 20: 683-690. Link: https://bit.ly/3cLjEKs

22. Kong X, Wang F, Niu Y, Wu X, Pan Y (2018) A comparative study on the effect of promoting the osteogenic function of osteoblasts using isoflavones from Radix Astragalus. Phytother Res 32: 115-124. Link: https://bit.ly/2LIgYBd

23. Tou JC (2015) Resveratrol supplementation affects bone acquisition and osteoporosis: Pre-clinical evidence toward translational diet therapy. Biochim Biophys Acta 1852: 1186-1194. Link: https://bit.ly/3bl6In3

24. Horcajada MN, Offord E (2012) Naturally plant-derived compounds: role in bone anabolism. Curr Mol Pharmacol 5: 205-218. Link: https://bit.ly/2Zmb8h8

25. Anderson EF (2001) The Cactus Family. Ed. Timber Press, Oregon 15-72.

26. Stintzing FC, Carle R (2005) Cactus stems (Opuntia spp.): a review on their chemistry, technology, and uses. Mol Nutr Food Res 49: 175-194. Link: https://bit.ly/2ZmypzA

27. Del Socorro Santos Díaz $M$, Barba de la Rosa AP, Héliès-Toussaint $C$ Guéraud F, Nègre-Salvayre A, et al. (2017) Opuntia spp.: Characterization and Benefits in Chronic Diseases. Oxid Med Cell Longev 2017: 8634249. Link: https://bit.ly/3cOYUkK

28. Aruwa CE, Amoo SO, Kudanga T (2018) Opuntia (Cactaceae) plant compounds, biological activities and prospects - A comprehensive review. Food Res Int 112: 328-344. Link: https://bit.ly/2WJZMlk

29. Cauley JA (2015) Estrogen and bone health in men and women. Steroids 99 11-15. Link: https://bit.ly/2XbLoBj

Citation: Gili V, Laiuppa JA, Santillán GE (2020) Aqueous extract from Opuntia megapotamica fruit pulp promotes osteoblast activity. A technical note and preliminary report. Int J Spine Res 2(1): 037-045. DOI: https://dx.doi.org/10.17352/ijsr.000012 
30. Torre E (2017) Molecular signaling mechanisms behind polyphenol-induced bone anabolism. Phytochem Rev 16: 1183-226. Link: https://bit.ly/2XbLdG9

31. Zhao H, Zhao N, Zheng P, Xu X, Liu M, et al. (2018) Prevention and Treatment of Osteoporosis Using Chinese Medicinal Plants: Special Emphasis on Mechanisms of Immune Modulation. J Immunol Res 2018: 6345857. Link: https://bit.ly/2LLhNJH

32. Fernández ML, Lin EC, Trejo A, McNamara DJ (1994) Prickly pear (Opuntia sp.) pectin alters hepatic cholesterol metabolism without affecting cholestero absorption in guinea pigs fed a hypercholesterolemic diet. J Nutr 124: 817 824. Link: https://bit.ly/2AEYOOW

33. Trejo-González A, Gabriel-Ortiz G, Puebla-Pérez AM, Huízar-Contreras MD Munguía-Mazariegos MR, et al. (1996) A purified extract from prickly pear cactus (Opuntia fuliginosa) controls experimentally induced diabetes in rats. $J$ Ethnopharmacol 55: 27-33. Link: https://bit.ly/2zXf3Wl

34. Ennouri M, Fetoui $H$, Bourret E, Zeghal N, Guermazi F, et al. (2006) Evaluation of some biological parameters of Opuntia ficus indica. 2. Influence of seed supplemented diet on rats. Bioresour Technol 97: 1382-1386. Link: https://bit.ly/2zXf2IC

35. Heinrich M, Frei HB, Leonti M (2014) A perspective on natural products research and ethnopharmacology in Mexico: the eagle and the serpent on the prickly pear cactus. J Nat Prod 77: 678-689. Link: https://bit.ly/2Xey2nW

36. Lee JC, Kim HR, Kim J, Jang YS (2002) Antioxidant property of an ethanol extract of the stem of Opuntia ficus-indica var. saboten. J Agric Food Chem 50: 6490-6496. Link: https://bit.ly/2WPOrlz

37. Coria Cayupán YS, Ochoa MJ, Nazareno MA (2011) Health-promoting substances and antioxidant properties of Opuntia sp. fruits. Changes in bioactive-compound contents during ripening process. Food Chem 126: 514 519. Link: https://bit.ly/3g0g80

38. Kim SH, Jeon BJ, Kim DH, Kim TI, Lee HK, et al. (2012) Prickly pear cactus (Opuntia ficus indica var. saboten) protects against stress-induced acute gastric lesions in rats. J Med Food 15: 968-973. Link: https://bit.ly/3e1BRDz

39. Ammar I, Bardaa S, Mzid M, Sahnoun Z, Rebaii T, et al. (2015) Antioxidant, antibacterial and in vivo dermal wound healing effects of Opuntia flower extracts. Int J Biol Macromol 81: 483-490. Link: https://bit.ly/36dD870

40. Smida A, Ncibi S, Taleb J, Saad AB, Ncib S, et al. (2017) Immunoprotective activity and antioxidant properties of cactus (Opuntia ficus indica) extract against chlorpyrifos toxicity in rats. Biomed Pharmacother 88: 844-851. Link: https://bit.ly/2ZjRgev

41. Park EH, Kahng JH, Lee SH, Shin KH (2001) An anti-inflammatory principle from cactus. Fitoterapia 72: 288-290. Link: https://bit.ly/2LK4990

42. Ahmad A, Davies J, Randall S, Skinner GR (1996) Antiviral properties of extract of Opuntia streptacantha. Antiviral Res 30: 75-85. Link: https://bit.ly/2zgsjG1

43. Kaur M, Kaur A, Sharma R (2012) Pharmacological actions of Opuntia ficus indica: A Review. JAPS 2: 15-18. Link: https://bit.ly/2Zj7zrN

44. Budinsky A, Wolfram R, Oguogho A, Efthimiou Y, Stamatopoulos Y, et al. (2001) Regular Ingestion of Opuntia Robusta Lowers Oxidation Injury. Prostaglandins Leukot Essent Fatty Acids 65: 45-50. Link: https://bit.ly/2XeqT6R

45. Hahm SW, Park J, Oh SY, Lee CW, Park KY, et al. (2015) Anticancer properties of extracts from Opuntia humifusa against human cervical carcinoma cells. $J$ Med Food 18: 31-44. Link: https://bit.ly/3bPZZaK

46. Hahm SW, Park J, Park KY, Son YS, Han H (2016) Extracts of Opuntia humifusa fruits inhibit the growth of AGS human gastric adenocarcinoma cells. Prev Nutr Food Sci 21: 31-37. Link: https://bit.ly/2XhAFoO

47. Aguilera-Barreiro MA, Rivera-Márquez JA, Trujillo-Arriaga HM, Tamayo JA Barreira-Mercado E, et al. (2013) Intake of dehydrated nopal (Opuntia ficus indica) improves bone mineral density and calciuria in adult Mexican women. Food Nutr Res 57: 103402. Link: https://bit.ly/2WJYMh4
48. Kang J, Park J, Choi SE, Igawa S, Song Y (2012) Opuntia humifusa Supplementation Increased Bone Density by Regulating Parathyroid Hormone and Osteocalcin in Male Growing Rats. Int J Mol Sci 13: 6747-6756. Link: https://bit.ly/2XgKFij

49. Hernández-Becerra E, Gutiérrez-Cortez E, Del Real A, Rojas-Molina A, Rodríguez García M, et al. (2017) Bone Mineral Density, Mechanical, Microstructura Properties and Mineral Content of the Femur in Growing Rats Fed with Cactus Opuntia ficus indica (L.) Mill. (Cactaceae) Cladodes as Calcium Source in Diet. Nutrients 9: 108. Link: https://bit.ly/2LEX8aa

50. Ko BS, Lee HW, Kim DS, Kang S, Ryuk JA, et al. (2014) Supplementing with Opuntia ficus-indica Mill and Dioscoreanipponica Makino extracts synergistically attenuates menopausal symptoms in estrogen-deficient rats. J Ethnopharmacol 155: 267-276. Link: https://bit.ly/2ylu7gE

51. Yang El, Lee $\mathrm{CH}, \mathrm{Kim}$ YS (2016) The effect of alcohol insoluble polysaccharide (AIP) from Opuntia humifusa on osteoporosis in ovariectomized mice. Journal of Food Biochemistry 40: 707-714. Link: https://bit.ly/36e7RSp

52. Park J, Hahm SW, Son YS (2011) Effects of Cheonnyuncho (Opuntia humifusa) Seeds Treatment on the Mass, Quality, and the Turnover of Bone in Ovariectomized Rats. Food Sci Biotechnol 20: 1517-1524. Link: https://bit.ly/2zhudGm

53. Hwang HJ, Jung BM, Kim M (2011) ROS Scavenging Effect and Cell Viability of Opuntia humifusa Extract on Osteoblastic MC3T3-E1 Cells. Journal of Life Science 21: 1752-1760. Link: https://bit.ly/3e3709U

54. Gili V (2016) Efectos de la administración oral de opuntia megapotamica (Cactaceae) sobre la glucemia y los lípidos de ratas diabéticas. Link: https://bit.ly/2Tnxtab

55. Mizrahi Y, Nerd A, Nobel PS (1997) Cacti as Crops. Horticultural Reviews 18: 291-320. Link: https://bit.ly/2zW998E

56. Sharapin N, Santos E, Sharapin N,Rocha LM, Carvalho ES, et al. (2000) Fundamentos de tecnologia de Produtos Fitoterápicos. Cyted Santafé de Bogotá 145-157. Link: https://bit.ly/2ZizyYM

57. Repetto G, del Peso A, Zurita JL (2008) Neutral red uptake assay for the estimation of cell viability/cytotoxicity. Nat Protoc 3: 1125-1131. Link: https://bit.ly/36e7qrf

58. Geserick P, Hupe M, Moulin M, Wong WW, Feoktistova M, et al. (2009) Cellular IAPs inhibit a cryptic CD95-induced cell death by limiting RIP1 kinase recruitment. J Cell Biol 187: 1037-1054. Link: https://bit.ly/36dD9J0

59. Hoemann CD, El-Gabalawy H, McKee MD (2009) In vitro osteogenesis assays: Influence of the primary cell source on alkaline phosphatase activity and mineralization. Pathologie Biologie 57: 318-323. Link: https://bit.ly/3e3K5LC

60. Ayala-Peña VB, Scolaro LA, Santillán GE (2013) ATP and UTP stimulate bone morphogenetic protein-2, -4 and -5 gene expression and mineralization by rat primary osteoblasts involving PI3K/Akt pathway. Experimental Cell Research 319: 2028-2036.

61. Laiuppa JA, Santillán GE (2016) Effect of Combined Action of Extracellular ATP and Elevated Calcium on Osteogenic Differentiation of Primary Cultures from Rat Calvaria. J Cell Biochem 117: 2658-2668. Link: https://bit.ly/3dZSgb

62. Pirih FQ, Abayahoudian R, Elashoff D, Parhami F, Nervina JM, et al. (2008) Nuclear receptor profile in calvarial bone cells undergoing osteogenic versus adipogenic differentiation. J Cell Biochem 105: 1316-1326. Link: https://bit.ly/2TpuLkB

63. Weivoda MM, Hohl RJ (2012) Geranylgeranyl pyrophosphate stimulates PPARy expression and adipogenesis through the inhibition of osteoblasts differentiation. Bone 50: 467-476. Link: https://bit.ly/2LEWidw

64. Vater $C$, Kasten $P$, Stiehler M (2011) Culture media for the differentiation of mesenchymal stromal cells. Acta Biomater 7: 463-477. Link: https://bit.ly/2Xcfy7w

Citation: Gili V, Laiuppa JA, Santillán GE (2020) Aqueous extract from Opuntia megapotamica fruit pulp promotes osteoblast activity. A technical note and preliminary report. Int J Spine Res 2(1): 037-045. DOI: https://dx.doi.org/10.17352/ijsr.000012 
65. Deters AM, Meyer U, Stintzing FC (2012) Time-dependent bioactivity of preparations from cactus pear (Opuntia ficus indica) and ice plant (Mesembryanthemum crystallinum) on human skin fibroblasts and keratinocytes. J Ethnopharmacol 142: 438-444. Link: https://bit.ly/3cMynEZ

66. Naselli F, Tesoriere L, Caradonna F, Bellavia D, Attanzio A, et al. (2014) Anti-proliferative and pro-apoptotic activity of whole extract and isolated indicaxanthin from Opuntia ficus-indica associated with re-activation of the onco-suppressor p16(INK4a) gene in human colorectal carcinoma (Caco-2) cells. Biochem Biophys Res Commun 450: 652-658. Link: https://bit.ly/2WNdWC6

67. Orimo H (2010) The Mechanism of Mineralization and the Role of Alkaline Phosphatase in Health and Disease. J Nippon Med Sch 77: 4-12. Link: https://bit.ly/3gch1n9

68. Sabokbar A, Millett PJ, Myer B, Rushton N (1994) A rapid, quantitative assay for measuring alkaline phosphatase activity in osteoblastic cells in vitro. Bone Miner 27: 57-67. Link: https://bit.ly/3g5AOEz

69. Glimcher MJ (2006) Bone: nature of the calcium phosphate crystals and cellular, structural, and physical chemical mechanisms in their formation. Rev Miner Geochem 64: 223-282. Link: https://bit.ly/2WLq32p
70. Anderson HC, Garimella R, Tague SE (2005) The role of matrix vesicles in growth plate development and biomineralization. Front Biosci 10: 822-837. Link: https://bit.ly/2ZjDcS5

71. Iravani S (2011) Green Synthesis of Metal Nanoparticles Using Plants. Green Chemistry 13: 2638-2650. Link: https://rsc.li/2z6ipaa

72. Gopi D, Kanimozhi K, Bhuvaneshwari N, Indira J, Kavitha L (2014) Nove banana peel pectin mediated green route for the synthesis of hydroxyapatite nanoparticles and their spectral characterization. Spectrochim Acta A Mol Biomol Spectrosc 118: 589-597. Link: https://bit.ly/3e3oEKI

73. Buitrago-Vásquez M, Ossa-Orozco CP (2018) Hydrothermal synthesis of hydroxyapatite nanorods using a fruit extract template. DYNA 85: 283-288. Link: https://bit.ly/2Tk1vf6

74. Zhang G, Sun S, Banis MN, Li R, Cai M, et al. (2011) Morphology-Controlled Green Synthesis of Single Crystalline Silver Dendrites, Dendritic Flowers, and Rods, and Their Growth Mechanism. Cryst Growth Des 11: 2493-2499. Link: https://bit.ly/3cP1uXZ

75. 75. Liu S, Tao D, Zhang L (2012) Cellulose scaffold: A green template for the controlling synthesis of magnetic inorganic nanoparticles. Powder Technol 217: 502-509. Link: https://bit.ly/36cQEsw

\section{Discover a bigger Impact and Visibility of your article publication with} Peertechz Publications

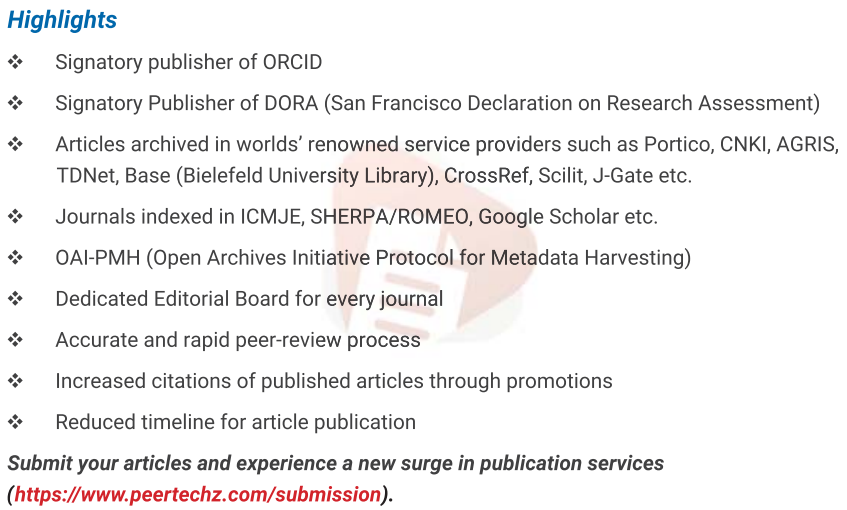

Peertechz journals wishes everlasting success in your every endeavours.

Copyright: (c) 2020 Gili V, et al. This is an open-access article distributed under the terms of the Creative Commons Attribution License, which permits unrestricted use, distribution, and reproduction in any medium, provided the original author and source are credited.

Citation: Gili V, Laiuppa JA, Santillán GE (2020) Aqueous extract from Opuntia megapotamica fruit pulp promotes osteoblast activity. A technical note and preliminary report. Int J Spine Res 2(1): 037-045. DOI: https://dx.doi.org/10.17352/ijsr.000012 